Theories of the State 


\title{
Theories of the State
}

\author{
The politics of liberal democracy
}

Patrick Dunleavy and Brendan O'Leary

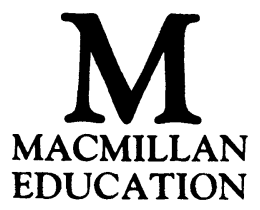


(C) Patrick Dunleavy and Brendan O'Leary 1987

All rights reserved. No reproduction, copy or transmission of this publication may be made without written permission.

No paragraph of this publication may be reproduced, copied or transmitted save with written permission or in accordance with the provisions of the Copyright Act 1956 (as amended), or under the terms of any licence permitting limited copying issued by the Copyright Licensing Agency, 7 Ridgmount Street, London WC1E 7AE.

Any person who does any unauthorised act in relation to this publication may be liable to criminal prosecution and civil claims for damages.

First published 1987

Published by

MACMILLAN EDUCATION LTD

Houndmills, Basingstoke, Hampshire RG21 2XS

and London

Companies and representatives

throughout the world

Typeset by Wessex Typesetters

(Division of The Eastern Press Ltd)

Frome, Somerset

British Library Cataloguing in Publication Data

Dunleavy, Patrick

Theories of the state: the politics of

liberal democracy.

1. State, The

I. Title II. O'Leary, Brendan

320.1'01 JC11

ISBN 978-0-333-38698-9

ISBN 978-1-349-18665-5 (eBook)

DOI 10.1007/978-1-349-18665-5 
To Donal O'Leary and Vincent Dunleavy 


\section{Contents}

List of Figures and Tables ix

Preface $\quad$ xi

1 Introduction 1

1.1 Controversies about the state 6

1.2 Structure of the book 9

2 Pluralism 13

2.1 Origins and development 13

$\begin{array}{ll}2.2 \text { Methods and values } & 17\end{array}$

2.3 Input politics $\quad 23$

2.4 State organization $\quad 41$

2.5 Crises $\quad 59$

3 The New Right 72

3.1 Origins and development 73

3.2 Methods and values $\quad 86$

3.3 Input politics $\quad 95$

3.4 State organization $\quad 108$

$\begin{array}{ll}3.5 \text { Crises } & 127\end{array}$ 
viii Contents

4 Elite Theory 136

4.1 Origins and development 137

4.2 Methods and values $\quad 145$

4.3 Input politics 153

4.4 State organization $\quad 164$

4.5 Crises 197

5 Marxism 204

5.1 Origins and development 204

5.2 Methods and values $\quad 216$

5.3 Input politics 223

5.4 State organization 236

5.5 Crises 259

6 Neo-Pluralism $\quad 271$

6.1 Origins and development 273

6.2 Methods and values $\quad 285$

6.3 Input politics 288

6.4 State organization $\quad 300$

6.5 Crises 315

7 Summing Up the State Debate 319

7.1 Focusing on the state 320

7.2 Overlaps and cleavages between theories

7.3 Common themes in theories of the state 327

7.4 Evaluating rival theories of the state 334

$\begin{array}{ll}\text { Bibliography } & 350\end{array}$

$\begin{array}{ll}\text { Index } & 370\end{array}$ 


\section{List of Figures and Tables}

Figures

1.1 Ideological perspectives on state intervention 8

2.1 Convergence in party competition 29

2.2 Cumulative and cross-cutting cleavages 61

3.1 A prisoner's dilemma game 80

3.2 A chicken game 81

3.3 Why government agencies over-supply their outputs: Niskanen's model 118

4.1 The main sub-types of elite theory models of the state 187

5.1 Marxist conceptions of the 'relative autonomy' of the state 258

7.1 Overlaps between theories of the state 323

7.2 Relations between values, theories and evidence 337

\section{Tables}

3.1 A simple voting paradox 82

3.2 A more complex voting paradox: cyclical majorities 83

3.3 Political implications of policy programmes and politicians' reactions 
$\mathrm{x} \quad$ List of Figures and Tables

4.1 The impact of culture and elite behaviour on democracy

7.1 Cipher, guardian and partisan images in the five theories of the state

7.2 Key dimensions of variation within theories of the state

7.3 How five theories of the state view the components of values, theories and evidence in social science explanations 


\section{Preface}

No body of thought in social science can be very usefully assessed on its own. We make theoretical progress by comparing and contrasting one interpretation with another. Yet much of the available literature in political science is unhelpful, since it largely consists of expositions of a single theoretical viewpoint by someone committed to that intellectual approach and normally disinclined to say much about alternatives. The problem of comparing one theory with another is most acute for new students, who are often asked to wrestle with literature written by authors from radically different world-views.

This book developed from a series of joint lectures on the theory of the state given between 1983 and 1986 to our students at the LSE. We have tried to advance beyond existing statements of individual theories of the state in three fundamental ways. First, we have carefully structured the book so that each theory we describe is covered in a comparable format to the other viewpoints. By describing the same elements in each approach we hope that student readers in particular will find it much easier to refer backwards and forwards between theories, and to establish where they differ or converge. The final chapter sets out in a detailed way the points of overlap and divergence that we have found instructive, and argues that each of our five theories of the 
liberal democratic state confronts a similar set of internal options for characterizing state/society relations.

Second, we have tried to write the book in a way which gives the most compelling and clearest account possible of each of the theories included. This aim created dilemmas which cannot be resolved to the satisfaction of all our readers. Many parts of the theories we cover are not yet systematized different writers within each approach take individually distinctive views, often partially contradicting each other. We have seen the task of exegesis as requiring us to sift the available interpretations and to draw attention to the most fundamental differences - while simultaneously running together those variations of terminology, argument or method which seemed to us less fundamental. The result is that we have constructed a set of deliberately simplified theoretical positions that will not be wholly subscribed to by any one author or set of authors. We discuss some major internal divisions within each of the five theories of the state covered here, but this elaboration is unlikely to satisfy readers who hunger after total respect for the integrity of every modern theoretician's thought. We regret the sacrifice of detail and biographical sensitivity entailed but believe that in developing an effective comparative picture this cost is worthwhile.

Third, we have tried hard to avoid the anachronism which commonly afflicts comparative discussions of theoretical positions in political science. Our account is specifically orientated to explaining how theories of the state analyse contemporary Western liberal democracies. We have also accorded full weight to two recently influential liberal positions which most other accounts ignore or treat simply as unimportant variants of mainstream pluralism, namely, the new right view (Ch. 3) and neo-pluralism (Ch. 6).

This book is a completely joint work. Although we each produced first drafts for half the book, our previous discussions of ideas and our mutual revisions of each other's work have been so extensive that it is now impossible for us to say whose contribution is which. We both deserve half the credit or blame for any analysis contained here.

We probably could not have written what we have in any other institution. Our students in the 1983-6 period provided 


\section{Preface xiii}

a testing audience whose interest, curiosity and knowledge were a powerful stimulus. We are indebted to Alan Beattie, George Jones, Nick Ellison, Paul Heywood, and John Kelly at the LSE, and to Steven Kennedy, Keith Povey, Lorelei Watson and Sheila Dunleavy, all of whom commented helpfully on various drafts of chapters. To many others who helped in innumerable smaller ways go our many thanks.

Government Department

London School of Economics and Political Science
PATRIGK DUNLEAVY

BRENDAN O'LEARY 